\title{
Ecophysiological consequences of variability in diapause intensity
}

\author{
SINZO MASAKI \\ Laboratory of Entomology, Hirosaki University, Hirosaki, 036-8561 Japan; e-mail: Sinzo.Masaki@mb4.seikyou.ne.jp
}

Key words. Diapause, intensity, variability, cline, selection, genetics, polymorphism, seasonal cue

\begin{abstract}
Diapause intensity (DI) is a physiological trait represented by the duration of diapause under given conditions of environment. In many species, it is highly variable, probably being controlled by multiple genes and tends to form a cline in response to the latitudinal gradient of selection pressure. DI clines could be established artificially by crossing between lines of a cricket selected for different levels of DI, indicating the importance of genetic factors in the adaptive variation of DI. However, DI may be modified in response to seasonal cues both before and after the onset of diapause. Polymorphism in the intensity of prolonged diapause may split adults of a single population to emerge in different years. A unimodal distribution of DI may also result in polymodal termination of diapause, if DI variation is so large that chilling in one winter is not enough to terminate diapause for all members of a population. Bimodal termination of diapause after overwintering suggests heterogeneity in the final phase of diapause that requires high temperatures in spring. Polymodal termination of diapause subserves a bet-hedging strategy. Variability in DI thus provides insects with an important means of adaptation to their environments changing in space and time.
\end{abstract}

\section{INTRODUCTION}

Diapause is a major means of adaptation in insects to the seasonal changes of environment (Danilevsky, 1961; Beck, 1980; Saunders, 1982; Tauber et al., 1986; Danks, 1987). Diapausing insects may be highly tolerant to cold, heat, desiccation and starvation, but these abilities are adaptively significant only when diapause starts at an appropriate time. This timing is in most cases controlled by the response to seasonal cues such as daylength and temperature, and its geographic adjustment is accomplished by a photoperiodic cline as discovered for the first time by Danilevsky (1957) in the noctuid moth Acronycta rumicis (L.). The timing of diapause termination is also important for efficient utilization of resources, being primarily determined by diapause intensity (DI) and secondarily regulated by seasonal cues.

DI is a physiological trait that can be defined by the duration of diapause under given conditions of environment. Compared to the duration of nondiapause development, this trait is highly variable among different species of insects, ranging from only less than a few weeks to 10 years or more, and also within a species and even a population, although such variations are not always manifested in the field. Both genetic and environmental factors are involved in this variability. The high variability suggests that DI readily responds to selection pressure and that it plays a dynamic role in the evolution of seasonal life cycles.

To illustrate the ecophysiological importance of DI variability, I will take examples of DI variation in several different situations: clines along the climatic gradient, responses to artificial selection, seasonal regulation of diapause termination, and polymodal emergence from diapause. The purpose of this article is to promote further study on ecophysiological aspects of diapause rather than to review the available literature on the subject. Data obtained in our laboratory are mainly used, simply because I am familiar with them. Only where appropriate materials are not available, I rely on works from other laboratories.

\section{CLINAL VARIATION IN DI}

The easiest way to recognize variability in DI is to compare, under controlled experimental conditions, strains of insects collected from localities with widely different climatic conditions. The field cricket Teleogryllus emma (Ohmachi \& Matsuura) a univoltine species with an obligatory egg diapause, affords a typical example (Masaki, 1963). A northern strain of this species from Sapporo $\left(43^{\circ} \mathrm{N}\right.$, annual mean $\left.6.3^{\circ} \mathrm{C}\right)$ and a southern strain from Koti $\left(33^{\circ} \mathrm{N}, 16.5^{\circ} \mathrm{C}\right)$ are clearly different from each other in DI (Fig. 1). They terminate diapause at temperatures well above the developmental threshold, so that the egg stage including diapause can be determined at a high temperature $\left(25\right.$ or $\left.20^{\circ} \mathrm{C}\right)$. The hatching curves of the two strains overlap each other to some extent, but their peaks are clearly separated, the northern eggs hatching earlier than the southern eggs. Although the northern eggs develop faster after diapause than the southern ones, the large difference in the mean egg stage, 83 versus 132 days at $25^{\circ} \mathrm{C}$ or 112 versus 209 days at $20^{\circ} \mathrm{C}$, is mostly due to their different levels of DI. Reciprocal crosses between the two strains produced hybrids showing intermediate egg durations with means of 107 and 108 days at $25^{\circ} \mathrm{C}$ and 164 and 165 days at $20^{\circ} \mathrm{C}$. F2 progeny did not show any evidence for segregation of the two genotypes (Masaki, unpublished). Probably, DI is controlled by a polygenic system.

These circumstances favour the formation of a cline where there is a geographic gradient in selection pressure. DI in this field cricket indeed shows a latitudinal cline in the Japanese Islands, decreasing from south to north (Fig. 2; Masaki, 1965). Most of the geographic variation in the 


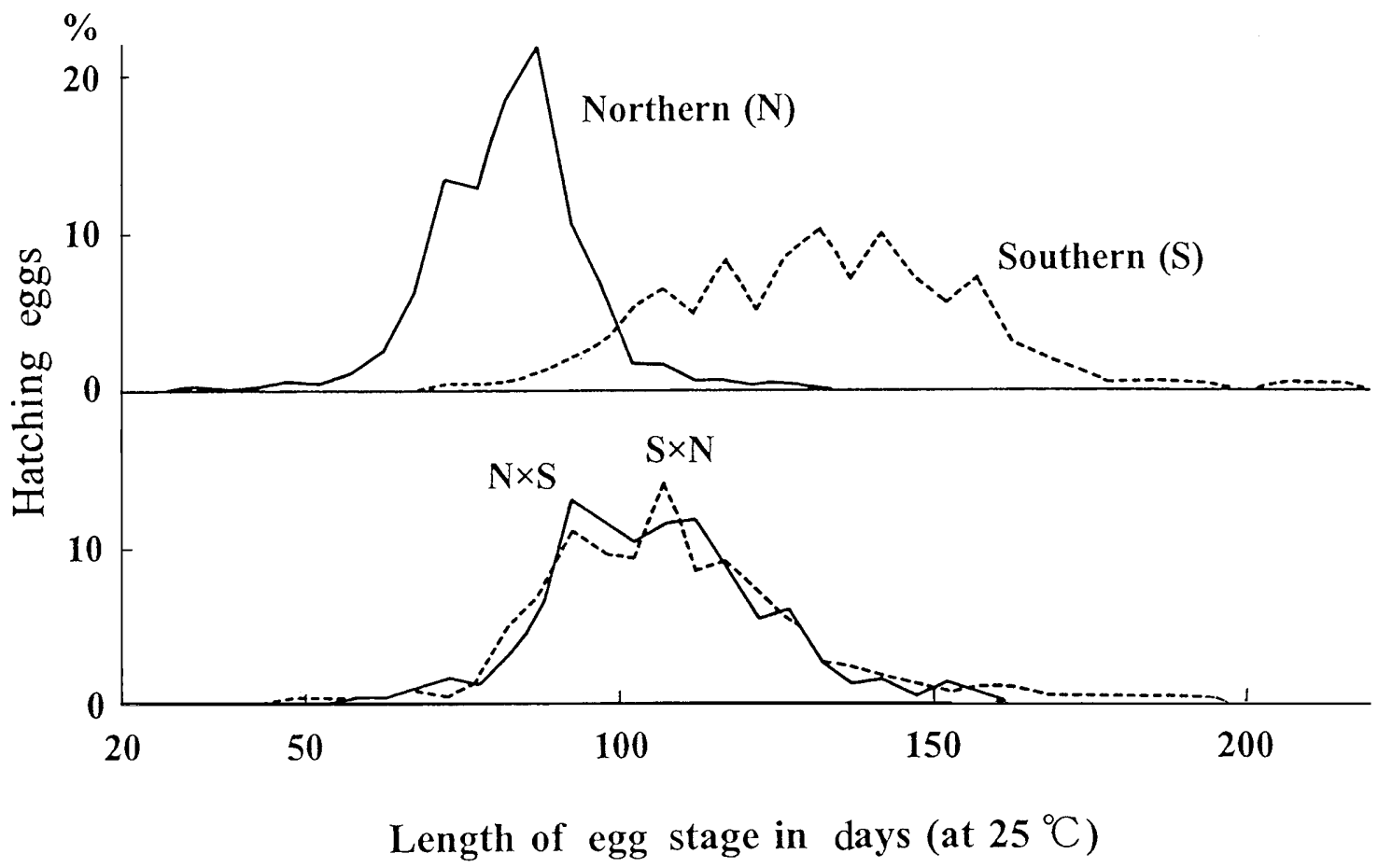

Fig. 1. Distributions of nymphs hatching from eggs of the northern (N, from Sapporo) and the southern (S, from Koti) strains of the Emma field cricket Teleogryllus emma (top) and their reciprocal hybrids (bottom) (Masaki 1963, modified).

egg duration can be ascribed to the regression on the temperature conditions of the original locality before and during the overwintering period (Masaki, 1965). The second and third laboratory-reared generations showed similar clines. Therefore, the observed cline is based on the genetic variation in DI - a result of selection by the local climatic conditions. Selection is probably effected through the risk of untimely termination of diapause

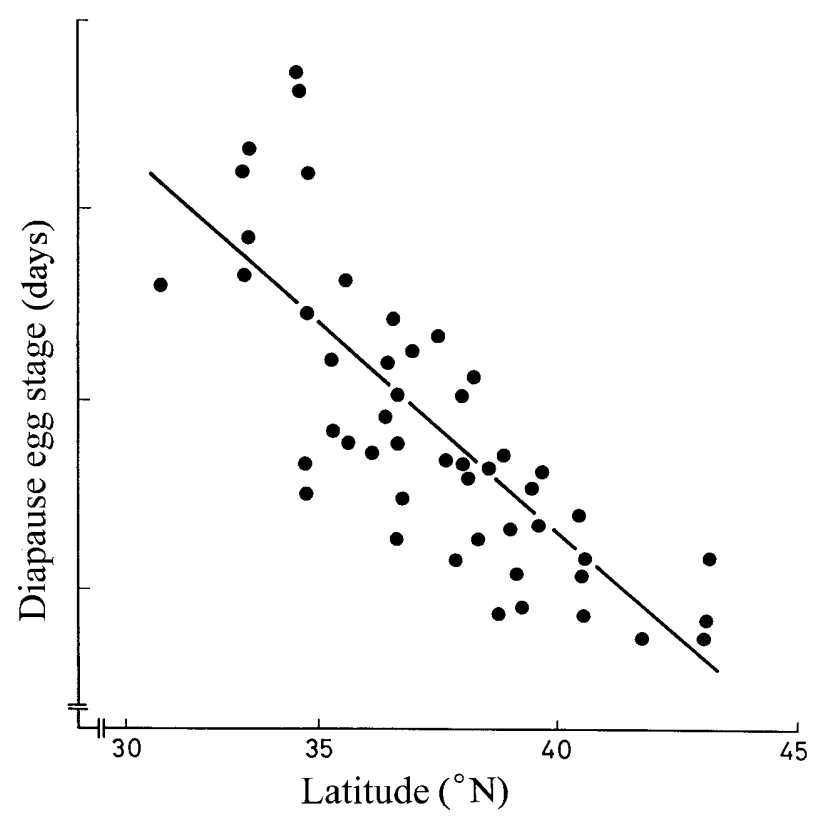

Fig. 2. Latitudinal cline in diapause intensity (DI) of T. emma in the Japanese Islands as represented by the mean egg durations at $26^{\circ} \mathrm{C}$ of many strains collected from different latitudes (Masaki 1965, modified). before winter. If the eggs terminate diapause and larvae hatch in response to warm weather in autumn, they would be killed by frost during winter. Such a risk is greater and, therefore, selection for a higher DI is stronger in the warmer south than in the cooler north.

If this inference is correct, similar clines might occur in other species of insects under similar selection pressures on DI (Masaki, 1999). In fact, the chrysomelid beetle Diabrotica virgifera LeConte and its closely related species (Krysan, 1982) and the rice grasshopper Oxya jezoensis Shiraki (Ando, unpublished) show DI clines declining from south to north. These species are all univoltine like T. emma.

However, reversed tendencies occur in multivoltine species such as the mosquito Wyeomyia smithii (Coquillett) (Bradshaw \& Lounibos, 1977), Drosophila auraria Peng and Drosophila triauraria Back \& Wheeler (Kimura, 1988), Tetranychus urticae Koch (Koveos et al., 1993) and Calliphora vicina Robineau-Desvoidy (Saunders, 2000). In these species, DI increases from south to north. Presumably, these tendencies might be due to genetic correlations between the incidence and intensity of diapause (Masaki, 1999) as clearly indicated in $C$. vicina (Saunders, 1987). The lower incidence of diapause in a southern multivoltine life cycle during the warm season might be associated with a lower DI.

On the other hand, DI for aestivation is directly proportional to the summer length of the original locality in both univoltine and multivoltine life cycles. Thus, DI clines increasing southward occur in the multivoltine populations of Mamestra brassicae L. (Fig. 3) (Masaki, 1956b; Grüner \& Sauer, 1988) and also in univoltine species such as the damselfly Lestes sponsa (Hansmann) 


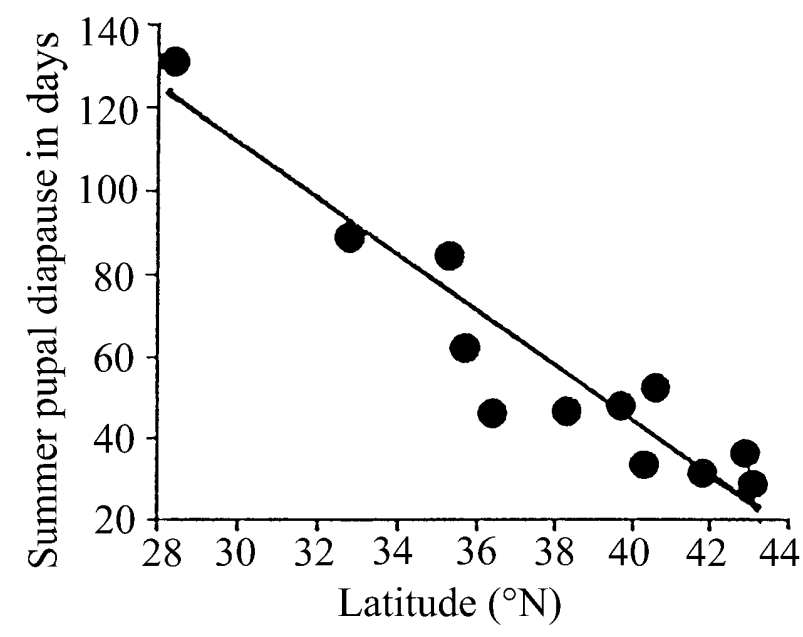

Fig. 3. Latitudinal cline in summer DI of Mamestra brassicae in the Japanese Islands as represented by the mean pupal durations in days at $26^{\circ} \mathrm{C}$ in darkness (Masaki 1956b, modified).

(Uéda, 1978) and the beetle Catops nigricans Spence (Topp, 1990).

\section{RESPONSE TO ARTIFICIAL SELECTION OF DI}

As DI clines are results of natural selection, they might be reconstructed by artificial selection. I continued such experiments in the last 20 years with the subtropical ground cricket Dianemobius fascipes (Walker) originated from Ishigaki Island $\left(24^{\circ} \mathrm{N}\right)$. In this population before selection, about $10-15 \%$ of eggs laid in 12-h daylength at $26^{\circ} \mathrm{C}$ undergo diapause lasting about 2 to 14 weeks with a mode around 10 weeks (Masaki, 1996).

Several lines derived from one group of adults collected in the field were selected for different egg durations in $12-\mathrm{h}$ daylength at $26^{\circ} \mathrm{C}$. The selection goals ranged from 2 to 22 weeks. The cumulative hatching curves for 22 to 70 generations (depending on the generation time of the selected lines) of selection are drawn in Fig. 4 just to show the high variability of DI. The curves distribute over a very wide range of the time axis, and they tend to diverge into 5 separate groups, reflecting the response to selection or the evolutionary flexibility of DI in this species. Examples of hatching patterns of the different lines are given in Fig. 5. These graphs together with the curves in Fig. 4 suggest that DI is probably controlled by multiple loci as in T. emma. A cline might be established by graded shifts in frequency of the genes giving additive effects on DI.

We attempted to create a cline by crossing between the lines selected for an intermediate DI (I, the egg stage of 14-16 weeks) and short DI (S, 7-9 weeks) or nondiapause $(\mathrm{N},<3$ weeks). When the mean durations of the diapause eggs deposited by the pure lines, F1, F2 and backcrosses of all the possible combinations are arranged according to the autosomal gene doses inherited from I line, they demonstrate a graded series of DI variations, suggesting additive effects of multiple loci. A maternal effect also exists, because the hybrid eggs are closer to the mother than to the father (Fig. 6). Epistatic and dominance components cannot be assessed readily because of the complicated distribution of egg duration (Fig. 4).

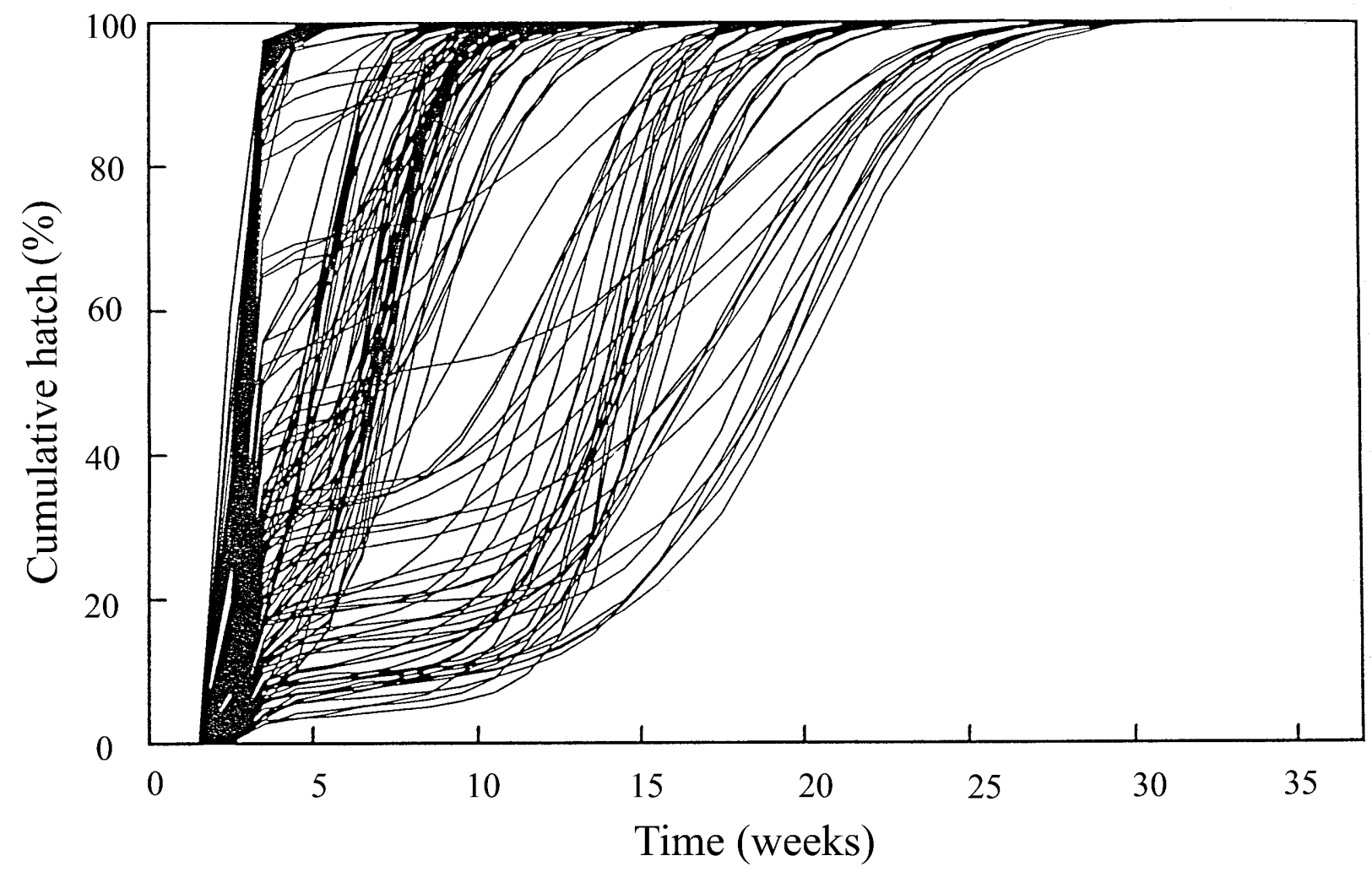

Fig. 4. Cumulative hatching curves at $26^{\circ} \mathrm{C}$ of 5 different lines of Dianemobius fascipes in all generations of selection for different DIs in 12 -h photoperiod at $26^{\circ} \mathrm{C}$, showing a high variability of DI. 


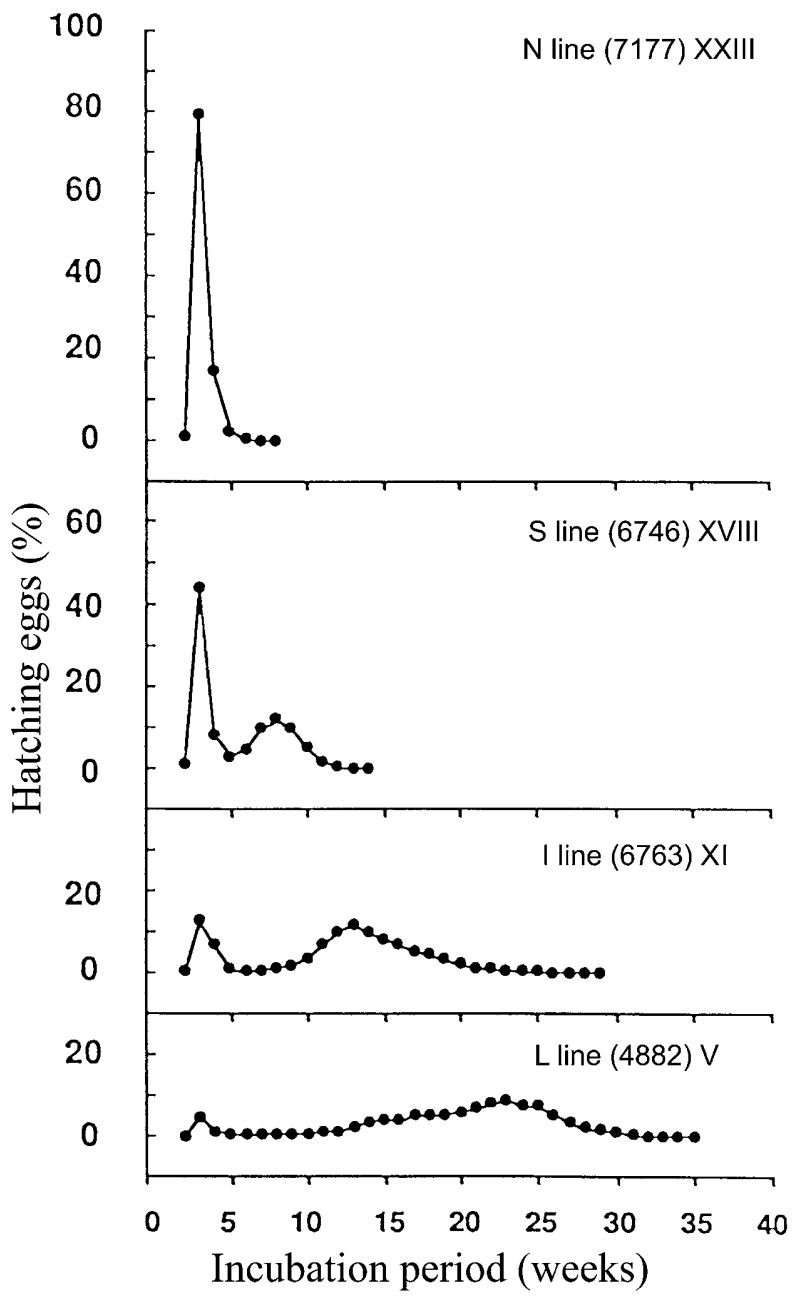

Fig. 5. Patterns of hatching distribution in four lines of $D$. fascipes selected for egg durations of $<3$ (nondiapause, N), 7-9 (short diapause, S), 14-15 (intermediate diapause, I), and $>21$ weeks (long diapause, L), respectively, in 12-h photoperiod at $25-26^{\circ} \mathrm{C}$. The generations (Roman numerals) and sample sizes (in brackets) are given for each strain.

The incidence of diapause of course changed with selection (Masaki, 1996), and there was a negative correlation between the incidence and intensity of diapause at least in the earlier generations of selection (Masaki, 1999). A similar correlation between the two diapause parameters has been found in C. vicina (Saunders, 1987). In the tobacco horn worm Manduca sexta (L.), by contrast, DI varied inversely with the incidence of diapause when the latter was decreased by later transfer from longto short-day cycles (Denlinger \& Bradfield, 1981).

In the ground cricket, the frequency of nondiapause eggs decreased, as might be expected, with the progress of selection for diapause, but nondiapause eggs did not disappear altogether even after 50 generations of selection against them. Moreover, the lower limit of DI remained unchanged, although the upper limit well responded to selection. In consequence, the phenotypic variation of DI increased with the progress of selection for a longer diapause (Fig. 5) - quite an unexpected and inexplicable result.

\section{PHENOTYPIC PLASTICITY OF DI}

Although the establishment of DI clines by artificial selection indicates the importance of genetic components in seasonal adaptation, DI is phenotypically plastic and drastically varies in response to seasonal cues particularly in those species entering diapause in different times of the year. In the noctuid moth $M$. brassicae, summer diapause is induced under long days and winter diapause under short days. DI is much higher for overwintering than for oversummering except for the subtropical population (Masaki, 1956b; Kimura \& Masaki, 1992). Summer diapause can be terminated at temperatures above the developmental threshold $\left(8^{\circ} \mathrm{C}\right)$ but winter diapause persists for more than 3 months at $25^{\circ} \mathrm{C}$ in darkness (Fig. 7).

Fine tuning of DI in summer is performed in response to the seasonal changes of daylength. DI is increased by the lengthening days from 15.3 to $16 \mathrm{~h}$ before the summer solstice, after which it is decreased by the shortening days from 16 to $15.3 \mathrm{~h}$ (Kimura \& Masaki, 1998). This response would reduce the time lag between the pupae formed before and after the summer solstice and result in a more synchronized autumn emergence of adults than otherwise.

Pupae of M. brassicae in winter diapause complete diapause when they are transferred from $25^{\circ} \mathrm{C}$ in darkness to a 16 -h photoperiod at $20^{\circ} \mathrm{C}$, so that their DI can be measured by the time required to resume development after the transfer (Kimura \& Masaki, 1998). The winter DI thus determined varies with the larval photoperiod (Fig. 8). A short photoperiod of $13 \mathrm{~h}$ tends to decrease winter DI but, in contrast to summer diapause, decreasing daylengths within a range from 15 to $13 \mathrm{~h}$ do not lower DI.

Regulation of DI in response to seasonal cues preceding the diapause stage occurs in a more conspicuous way in the geometrid moth Abraxas miranda Butler living in the southern warm districts of Japan. The larvae of this moth feed on an evergreen shrub and, in the overwintering generation, grow in a highly variable fashion and are observed feeding in winter as well as in autumn. As a result, they become fully fed and pupate continually at various times from autumn to early spring. They enter diapause and their DI, as assessed by the duration of the pupal stage at constant temperatures, remarkably varies with the pupation date, decreasing toward mid-winter in such a way that the large variation in pupation date is cancelled out and adults eclose synchronously in the spring (Fig. 9; Masaki, 1959). A similar adjustment of DI is also effected in summer diapause of this species induced under long daylengths. The summer-generation larvae start to pupate in June and DI decreases as they pupate later under shortening days. Owing to these regulatory responses in both summer and winter diapauses, there are two periods of well defined moth flight in autumn and spring, respectively (Masaki, 1958).

Another pattern of DI regulation can be seen in the univoltine arctiid moth Spilarctia imparilis Butler (Kimura et al., 1982). This species overwinters as halfgrown larvae forming a large aggregation in their nest 

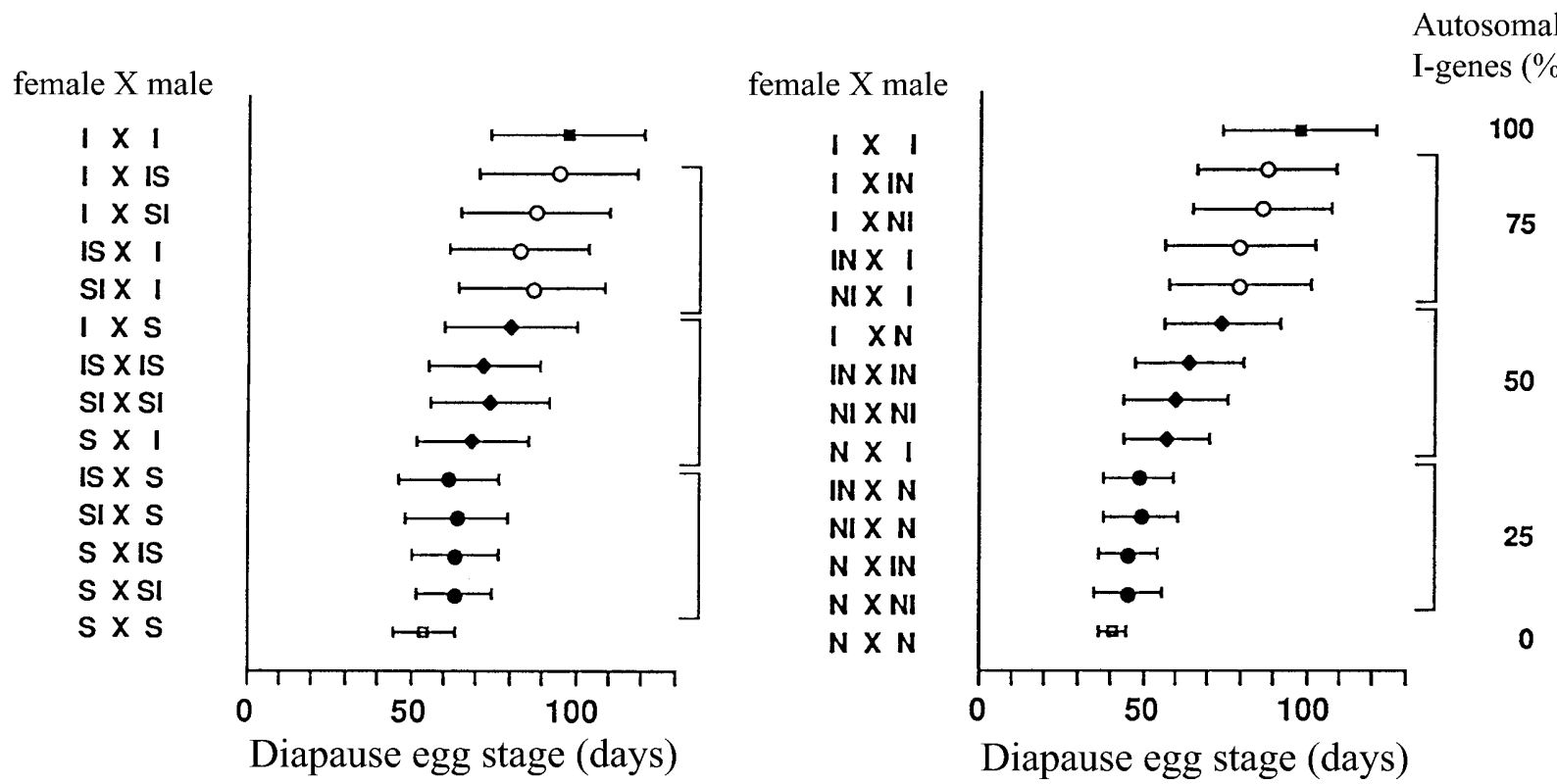

Fig. 6. Egg durations in various crosses between the lines of $D$. fascipes selected for nondiapause (N, $<3$ weeks), short (S, 7-9 weeks) and intermediate (I, 14-15 weeks) diapause durations. Left, I $\times$ S; right, I $\times$ N. Symbols indicate means and horizontal bars standard deviations. The crosses are arranged according to the expected proportion of autosomal genes inherited from the I line. (Data obtained by Takeshi Shibuta).

web. The larvae resume growth in early spring, leave the nest for feeding, and pupate in spring to early summer.

Those pupating early under the still short spring days lie dormant during summer but, as they pupate later under

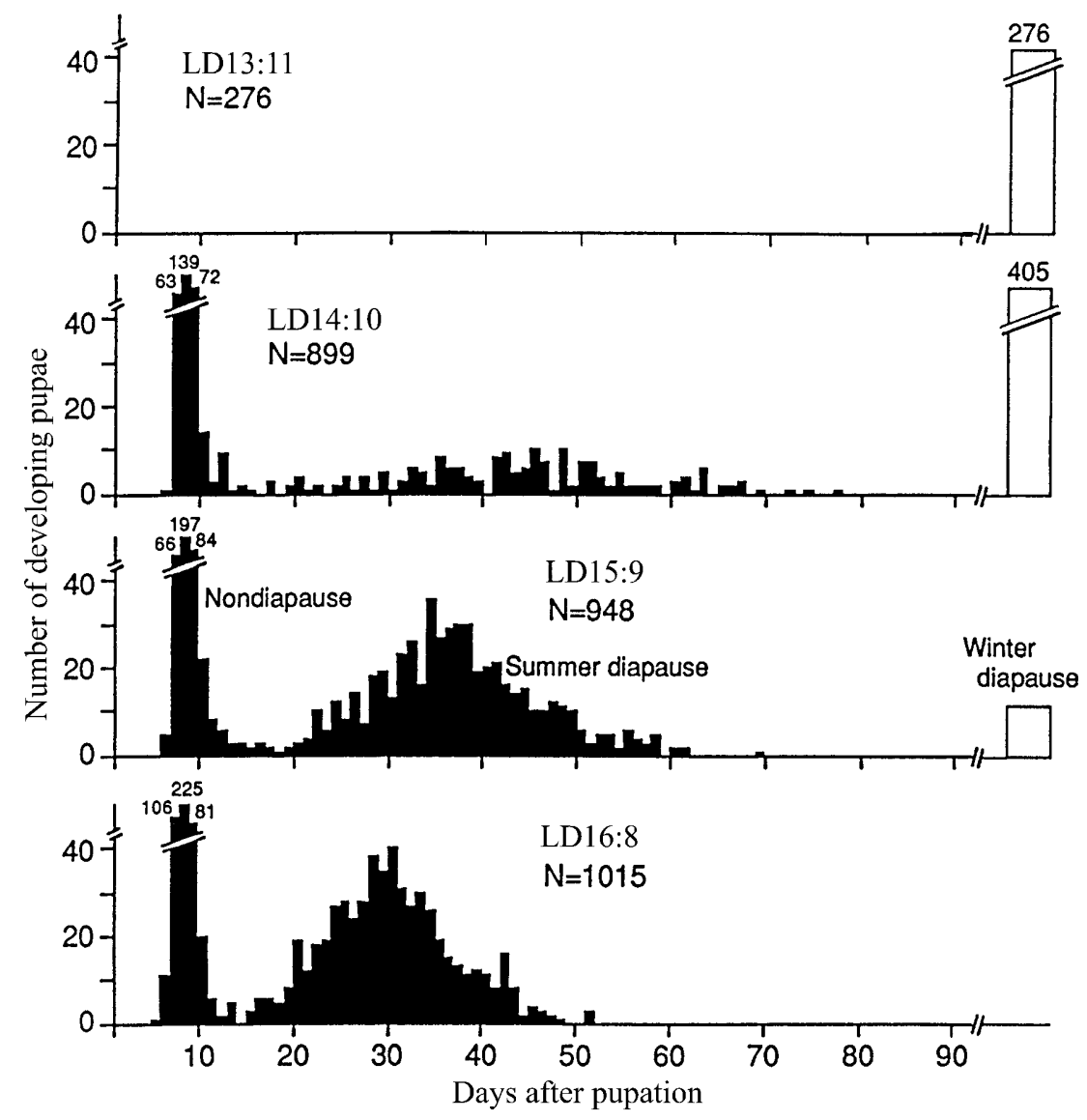

Fig. 7. Distributions of the pupal durations at $25^{\circ} \mathrm{C}$ in $M$. brassicae reared as larvae under different photoperiods (as shown in each panel) at $20^{\circ} \mathrm{C}$. Note the clear gap between summer diapause and winter diapause pupae. The latter do not develop within 90 days after pupation as represented by hollow histograms (Kimura \& Masaki, 1992, modified). 
ong days, they gradually decrease DI and finally avert diapause around the summer solstice (Fig. 10). Thus, the summer diapause response to photoperiod is contrary to that of $M$. brassicae. The contrasting patterns of aestivation in $S$. imparilis and $M$. brassicae are related to the difference in timing of pupation between the two species.

As already noted above, the sphingid moth $M$. sexta decreases its winter DI with the increasing number of short days in the larval stage. Therefore, larvae growing later and experiencing a larger number of short days would have lower DI after pupation so that they would catch up in diapause development with those growing earlier and exposed to a smaller number of short days. Surgical experiments show the involvement of the brain in this regulation (Denlinger \& Bradfield, 1981). The determination of DI seems to be linked to the endocrinological process of diapause induction.

In some cases, variation of DI caused by seasonal cues is without any adaptive significance. For example, DI in the adult of the bean bug Riptortus clavatus (Thunberg) is lower when diapause is induced in a photoperiod near the critical length than in a shorter one (Nakamura \& Numata, 2000), which means that DI in adults emerging earlier in autumn is lower than in those emerging later, contrary to the period of dormancy to be maintained before winter. Probably, the lowest DI of this species is enough for successful overwintering, and the observed tendency is an expression of the quantitative photoperiodic response. A similar quantitative effect may be exerted by temperature. In the pyrrhocorid bug Pyrrhocoris apterus L., DI is enhanced by a thermoperiod of $25^{\circ} \mathrm{C} / 15^{\circ} \mathrm{C}$ compared with that at constant $20^{\circ} \mathrm{C}$ or $25^{\circ} \mathrm{C}$ under diapause-inducing short days (Kalushkov et al., 2001).

Apart from the preliminary programming of DI, the course of diapause development itself is under the incessant control of environment in many species (Hodek \& Hodková, 1988). In the saturniid moth Dictyoploca japonica Moore, for example, summer diapause is terminated faster under short days and low temperatures than under long days and high temperatures (Fig. 11; Nagase \& Masaki, 1991). It is important to distinguish this immediate control of diapause development from the preliminary programming of DI, although seasonal cues are involved in both cases. The two different mechanisms would interact for the timely termination of diapause.

\section{VARIABILITY EXPRESSED AS POLYMODAL ECLOSION}

In insects with extended duration of diapause, emergence from a single diapausing cohort may occur over several years owing to polymodal termination of diapause. This emergence pattern constitutes a bethedging strategy to cope with unpredictable and catastrophic environmental risks (Waldbauer, 1978). Two basically different kinds of DI variability may underlie this life-cycle strategy.

Polymodal termination of diapause may be based on a genetic polymorphism in DI. The extended diapause induced by the interacting effect of short days and low temperatures in the sawfly Neodiprion sertifer (Geoffrey) in Canada probably represents such a situation (Sullivan \& Wallace, 1967). Adults of this sawfly eclose from cocoons after passing 1, 2, 3 or more winters in the field and in widely separated periods of about 100, 260, 400, and 750 days under constant conditions $\left(10^{\circ} \mathrm{C}\right)$ after cocoon spinning by eonymphs. Individuals belonging to the temporally separated groups of emergence would be genetically different from one another, although the underlying genetic mechanism has not been elucidated.

A similar polymodal termination of diapause over several years can also be derived from a population with a unimodal distribution of DI. The alpine katydid Eobiana japonica Bolivar enters diapause twice in the early and late embryonic stages termed as the initial and final diapause stages, respectively. Final diapause is terminated after overwintering once, but the eggs have to complete initial diapause to reach the final diapause stage. Some eggs terminate initial diapause after passing one winter, thus completing one generation in two years, but other eggs require two winters to reach the final diapause stage (Higaki \& Ando, 2000).

Although chilling enhances the termination of initial diapause in this katydid, it is not indispensable. When constantly kept at $25^{\circ} \mathrm{C}$, the cumulative percentage of eggs terminating initial diapause gradually increases until about 900 days of incubation without any evidence for a polymodal distribution of DI (Fig. 12). However, there is the possibility that this unimodal distribution of DI is split into two groups when the cold requirement is fulfilled after one winter only in those eggs with lower DI but not in others with higher DI. This situation was simulated by exposing eggs to two cycles of $3^{\circ} \mathrm{C}$ for 180 days and $25^{\circ} \mathrm{C}$ for 180 days, i.e., the entire treatment lasted about two years. This treatment split the unimodal distribution of DI into two peaks (Fig. 13). The first chilling period was enough to terminate the initial diapause for some eggs, but not for the rest that reached the late diapause stage only after the second chilling period, thus taking three years before hatching.

The situation described above can be mimicked even in species without extended diapause by exposing them to repeated short cycles of chilling and warming (Masaki, 1956a). In winter-diapause pupae of $M$. brassicae, for example, 2 to 4 separate peaks of adult emergence were obtained depending on the length of $5^{\circ} \mathrm{C} / 26^{\circ} \mathrm{C}$ cycle in darkness (Fig. 14). Cycles of $5^{\circ} \mathrm{C}$ for 15 days and $26^{\circ} \mathrm{C}$ for 10 days resulted in 4 peaks of adult eclosion at $26^{\circ} \mathrm{C}$ after the $3 \mathrm{rd}, 4 \mathrm{th}$, 5th and 6 th periods of chilling, respectively. Thus, a population with a normal distribution of DI was split into several groups, resulting in a polymodal emergence within a very short time lapse.

In this experiment, intermittent chilling is less effective than continuous chilling even when the total number of chilling days is the same in the two treatments. The DI weakened by chilling may be reversed to some extent during the inserted period of high temperature. Reversibility of DI is indeed clearly shown in the eggs of the leaf 


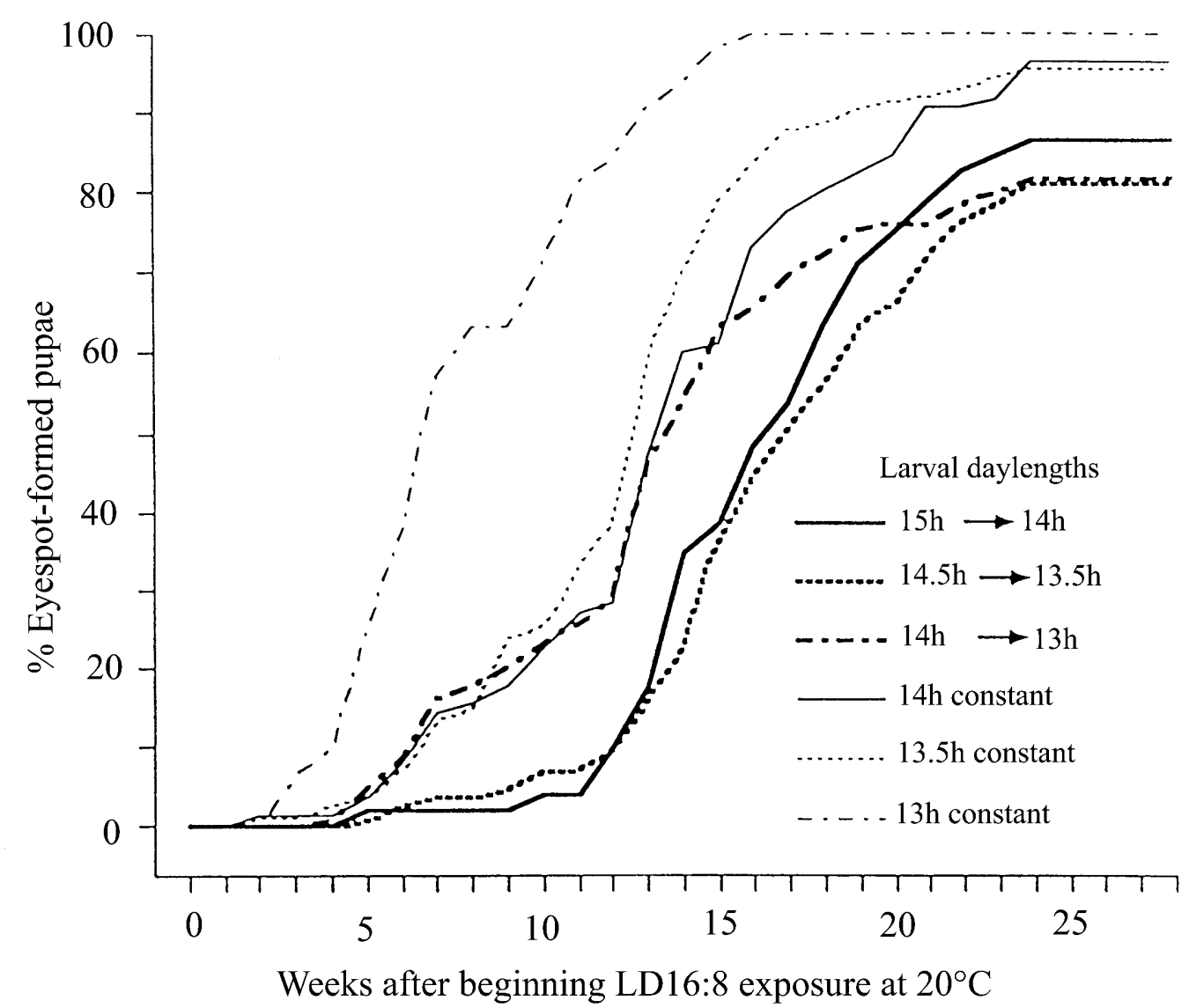

Fig. 8. Cumulative percentage of winter-diapause pupae of $M$. brassicae forming eyespots that had been reared under different conditions of photoperiod as larvae at $20^{\circ} \mathrm{C}$, kept at $25^{\circ} \mathrm{C}$ in darkness for 3 months after pupation, and then transferred to 16 -h photoperiod at $20^{\circ} \mathrm{C}$ to terminate diapause (Kimura \& Masaki, 1998).

beetle Atrachya menetriesi Faldermann (Ando, 1978) and the locust Locusta migratoria L. (Ando, 1993). DI as measured by the duration of chilling to terminate diapause undergoes cyclical changes in response to repeated cycles of a short chilling period followed by warming. There is a possibility that a similar reversal of the initial DI might

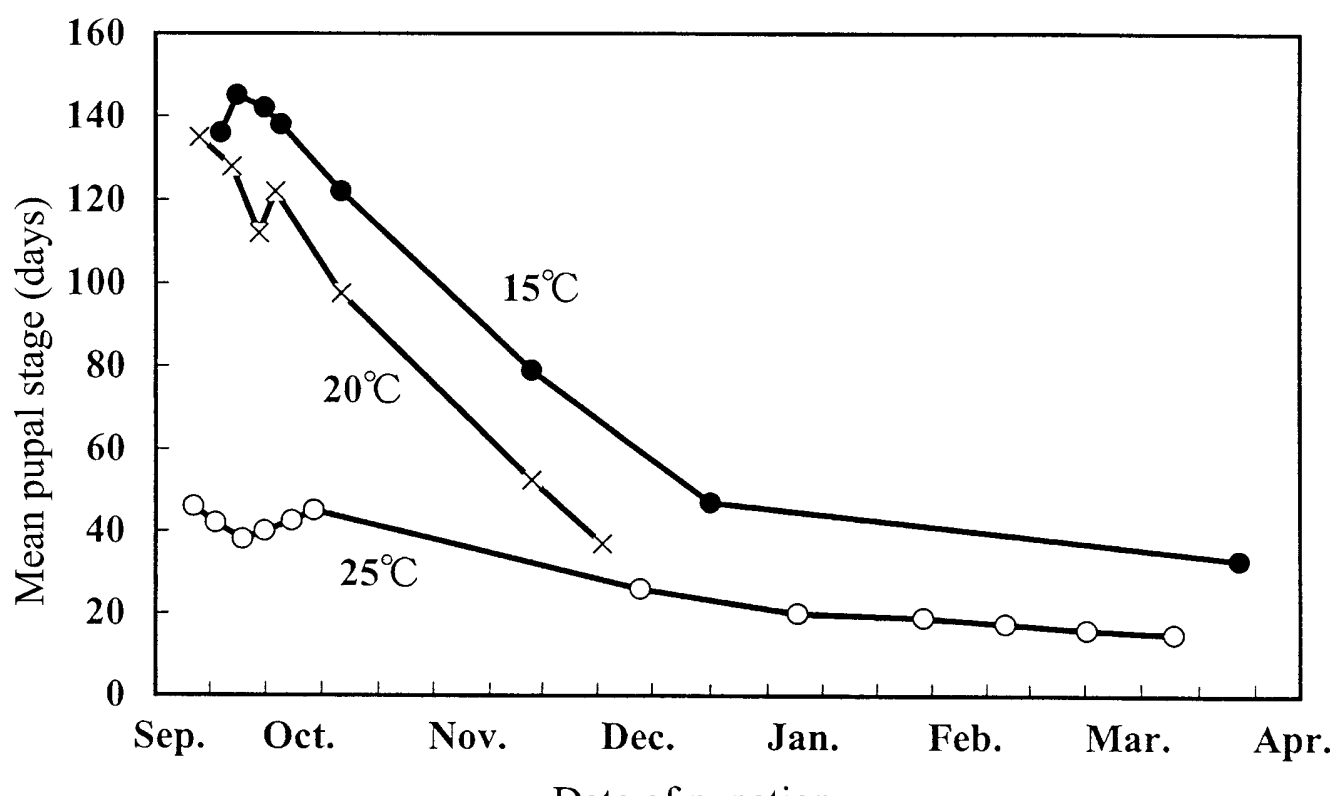

Date of pupation

Fig. 9. Mean pupal durations of Abraxas miranda transferred to three different temperatures from unheated insectary conditions immediately after pupation on different dates (Masaki, 1958). 


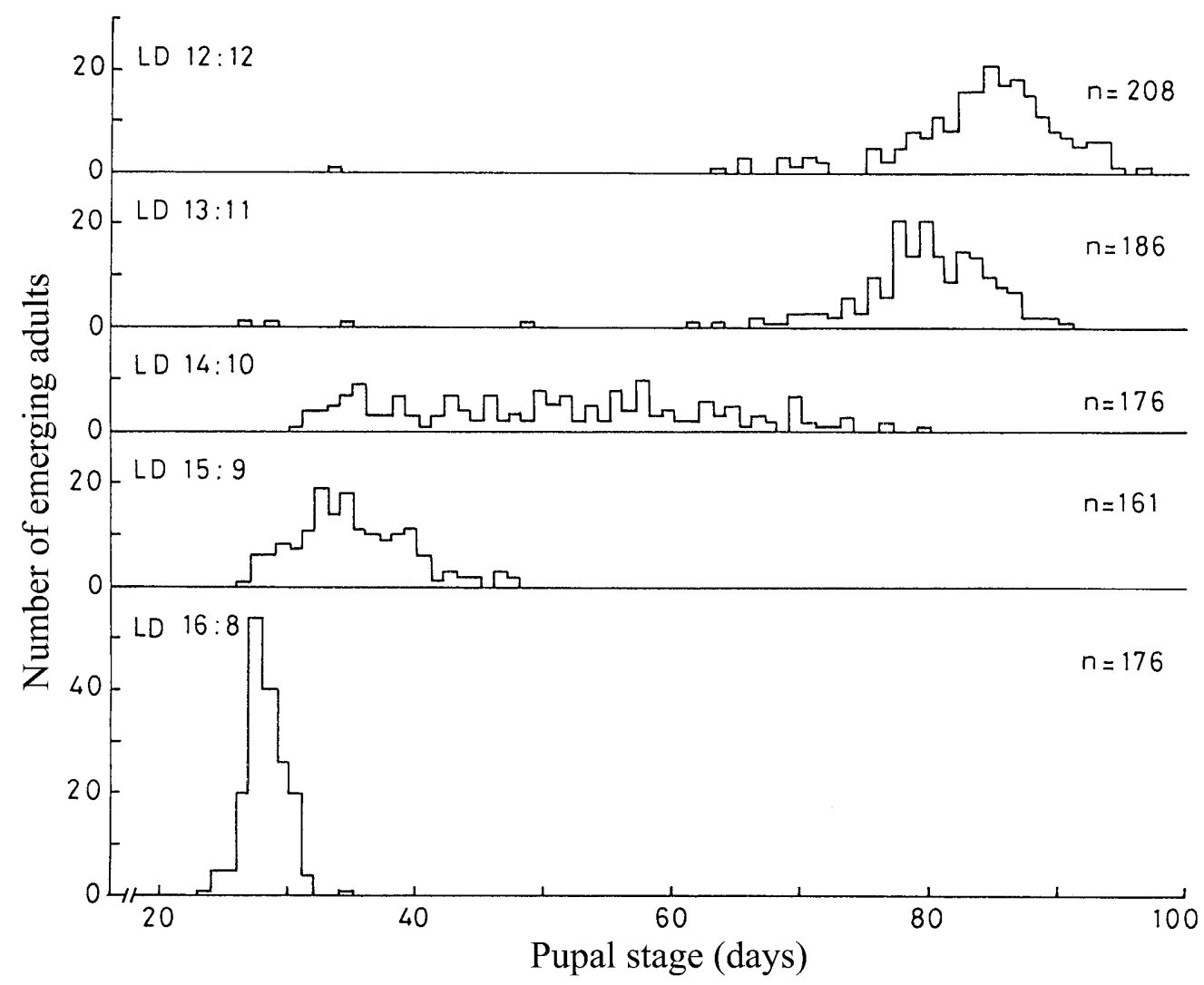

Fig. 10. Effects of larval photoperiods (left) at $20^{\circ} \mathrm{C}$ on the pupal DI as shown by the distribution of emerging adults at $20^{\circ} \mathrm{C}$ in Spilarctia imparilis. Sample sizes are indicated by n (right) (Kimura et al., 1982, modified).

stabilize the second overwintering in alpine species such as E. japonica. This may facilitate the evolution of the bet-hedging strategy of life cycle starting with increasing variability in DI.

\section{VARIABILITY IN DI EXPRESSED AFTER OVERWINTERING}

Another kind of polymodal termination of diapause may occur after passing only one winter (see Waldbauer, 1978 for review). Many species of insects are assumed to terminate winter diapause at some time before spring,
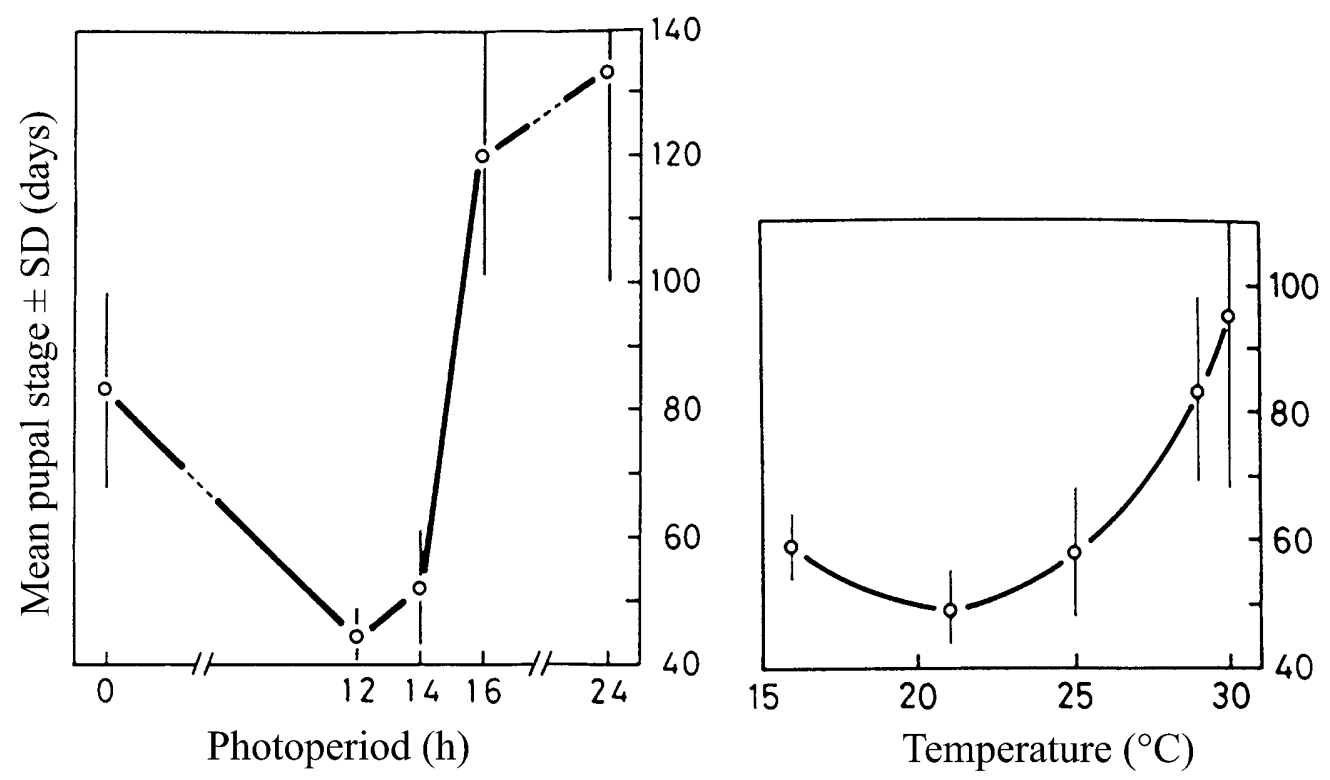

Fig. 11. Responses of aestivating pupae of Dictyoploca japonica to photoperiod (at $29^{\circ} \mathrm{C}$, left) and temperature (in darkness, right) as indicated by the pupal duration $\pm \mathrm{SD}$. Larvae were reared in natural long days $\left(15-16 \mathrm{~h}\right.$ ) at about $24^{\circ} \mathrm{C}$ (Nagase \& Masaki, 1991 , modified). 


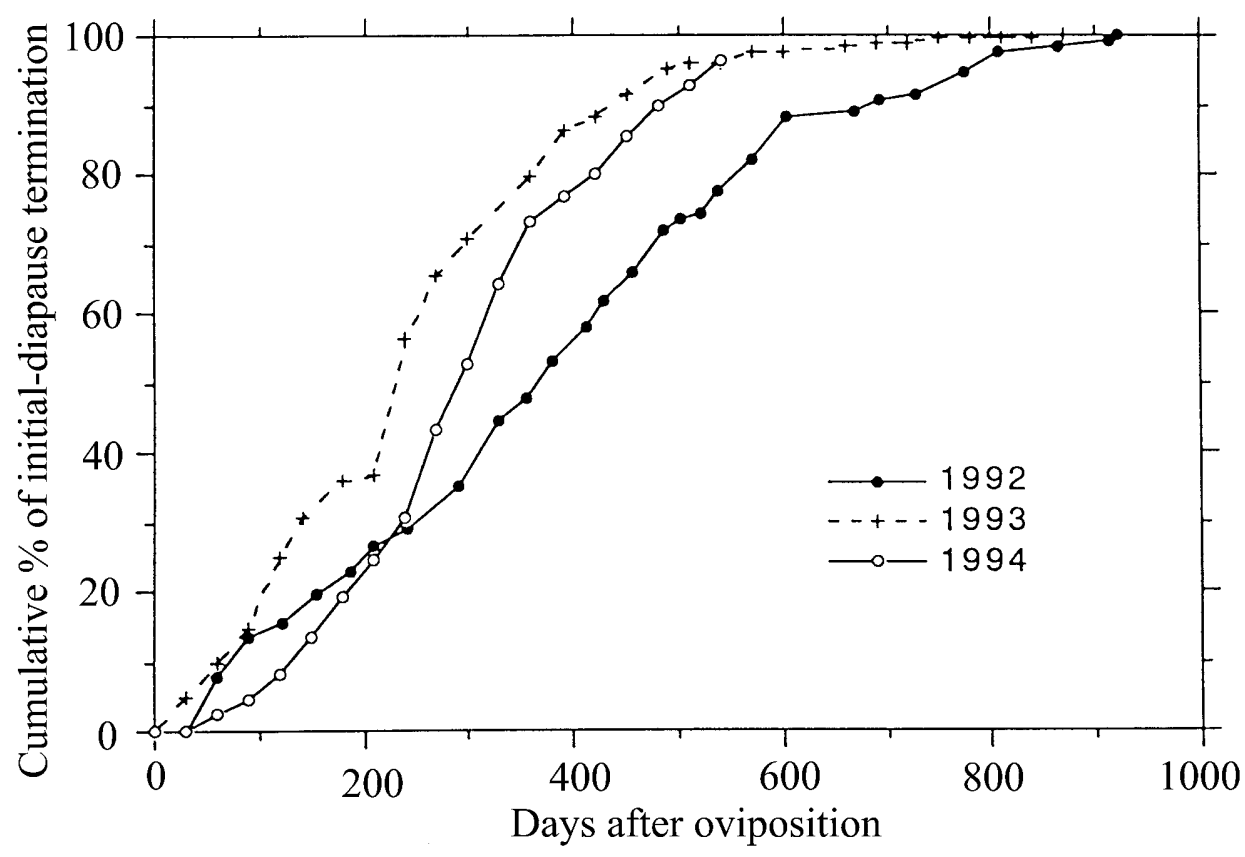

Fig. 12. Cumulative percentage of eggs terminating initial diapause in eggs of Eobiana japonica constantly kept at $25^{\circ} \mathrm{C}$ from oviposition. Results with eggs obtained in three different years are shown (Higaki \& Ando, 2000).

because they start development when transferred to a high temperature during winter. However, the resumption of development by an artificial warming does not necessarily mean the previous completion of diapause.

When diapausing eggs of the field cricket Teleogryllus commodus (Walker) are incubated after chilling at various temperatures above the developmental zero, the proportion of eggs starting to develop promptly on warming varies with temperature; to obtain $50 \%$ of such eggs at 30,25 and $20^{\circ} \mathrm{C}$, preliminary exposures to $10^{\circ} \mathrm{C}$ for 10, 22 and 59 days are required, respectively (Masaki et al., 1979). This observation indicates that diapause is terminated only after transfer to the high temperatures, because the proportion of diapause termination depends on the temperature after chilling. In other words, the final phase of diapause development is temperature-dependent and triggered by a high temperature. The diapauseterminating effect of a high temperature is further exemplified by the opportunisitic diapause in D. fascipes (Masaki, 1990). Under short days, many eggs enter diapause when incubated at $20^{\circ} \mathrm{C}$ but they start development promptly by a brief exposure to $25^{\circ} \mathrm{C}$ or higher temperatures.

If diapause is polymorphic in its final phase, the spring emergence from diapausing population should be polymodal. In fact, a bimodal adult eclosion from overwintering cocoons are observed in the saturniid moth Hyalophora cecropia (L.): A small peak of eclosion occurs about one month ahead of the major peak (Waldbauer \& Sternburg, 1973). A similar but more complicated polymodal spring eclosion from overwintered cocoons is observed in another saturniid Callosamia promethea Drury (Waldbauer, 1978). These eclosion patterns suggest that the overwintering pupae do not become free from diapause during winter. The final phase of diapause is completed in spring, and the bimodal termination of diapause reflects dimorphism in the final phase of diapause (Waldbauer \& Sternburg, 1986). The general belief that diapause is broken by the winter cold before spring in many species of insects should be carefully re-examined. A simplest way of testing this is to incubate diapausing insects, after chilling, at various temperatures above the developmental threshold.

The genetic basis of the bimodal emergence was confirmed by selection; the early-emerging group of $H$. cecropia usually occupied only less than $10 \%$ of the population but increased to more than $80 \%$ by selecting for several generations of early emergers (Waldbauer \& Sternburg, 1973).

Polymodal termination of winter diapause is not characteristic for saturniid moths. It may also occur in other groups of insects. In the Carposinid fruit moth Carposina sasakii (Matsumura), for example, adults emerge from overwintering cocoons in a bimodal fashion in Korea (Kim et al., 2000) as well as in Japan (Y. Ishiguri, personal communication). At Suwon (Korea) the first major peak occurs in late June and the second smaller peak in late July. (About 3-4\% of the cocoons overwinter twice, which represents another kind of polymorphism in DI.) A similar bimodality in diapause termination is observed at Kuroishi (Japan) but the relative sizes of the early and late peaks of emergence are reversed: the first smaller peak occurs in early June and the second major peak in late June.

At Kuroishi, the larvae of this moth leave the infested fruits from August to December to construct diapause cocoons in the soil. There is a tendency that the earlier the larvae spin diapause cocoons, the later the adult eclosion in the following spring. Therefore, two different hypotheses should be tested. DI in the overwintering 


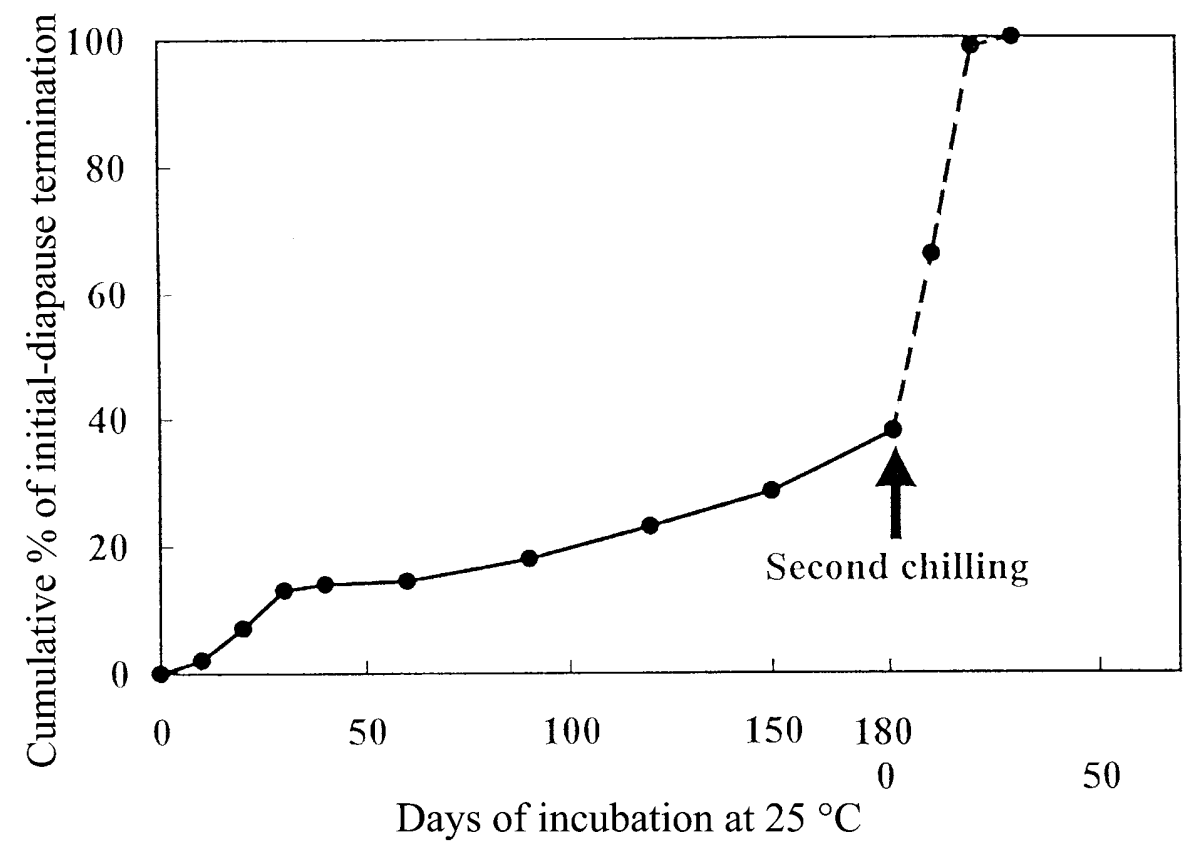

Fig. 13. Cumulative percentage of eggs terminating initial diapause in eggs of E. japonica exposed to two cycles of $3^{\circ} \mathrm{C}$ for 180 days and $25^{\circ} \mathrm{C}$ for 180 days. The arrow indicates the end of chilling (the start of warming) in the second cycle. The abscissa represents only the incubation time at $25^{\circ} \mathrm{C}$ in the two cycles. The continuous and broken lines indicates the initial diapause termination in the first and second periods of incubation at $25^{\circ} \mathrm{C}$, respectively (Higaki \& Ando, 2000, modified).

larvae is modified by the external conditions that larvae have experienced, or the population is genetically dimorphic in DI that affects the final phase of diapause. In either case, diapause should be terminated in spring after the soil temperature rises above the developmental threshold.

If this dimorphism in diapause is genetic, the difference in size of the early and late groups of emergence between the Suwon and Kuroishi populations suggests a difference in the relative fitnesses of the early and late groups between the two local populations. As suggested by Waldbauer (1978) polymodal termination of diapause might be bet-hedging to cope with unpredictable fluctuations of environmental conditions in spring. The selective forces involved may be inferred by comparing several populations from localities with various climatic conditions.

\section{CLOSING REMARKS}

DI plays an important role in adaptation to the seasonally and geographically changing environment because of its genetic and phenotypic variability. The variability in DI indicates that diapause may take various courses to terminate, or start for the next stage of development or reproduction. The determination of such courses before the diapause stage is regarded as a programming process, and probably interwoven into the sequence of events involved in diapause induction. This inference is compatible with the results of recent molecular genetic studies that diapause is not merely a shutdown of gene expression but it is a unique developmental pathway characterized by the expression of a novel set of genes (Flanagan et al., 1998). Moreover, the diapause pathway is comprised of different phases with different responses to environmental factors (Hodek \& Hodková, 1988) and, in many cases, it may take drastically different horotelic and tachytelic courses (Hodek, 1996).

In Bombyx mori L., a protein (esterase A4) serves as a "Time Interval Measuring Enzyme" or "TIME". This protein measures the duration of chilling required for terminating diapause (Kai et al., 1995, 1999). The timemeasuring function of this protein resides in its conformation and is triggered when a peptide "PIN" serving as "Peptidyl Inhibitory Needle" is dissociated from it (Tani et al., 2001). This system is the first elucidation of DI, at least one of its component processes, at a molecular level, although its relation to the diapause hormone (Yamashita, 1996) and the diapause-maintaining effect of polyols (Horie et al., 2000) remains to be elucidated. We expect this line of approach including analyses of the functions of other diapause-specific proteins will contribute to our further understanding of diapause in insects. There is the possibility that the genes controlling the diapause pathway (including DI) are derived from genes responsible for the temporal organization of the general developmental sequences. If so, different species of insects may share a common genetic background for the evolution of diapause.

However, different species of insects with different life styles have evolved diapause many times independently (e.g., Masaki, 1996) to adapt their life cycles to the seasonal changes. As a result, there is tremendous diversity in their diapause behaviours (e.g., Danks, 1991). Further exploration of ecological factors involved in such divergence is indispensable to deepen insight into the evolution of diapause in insects. 


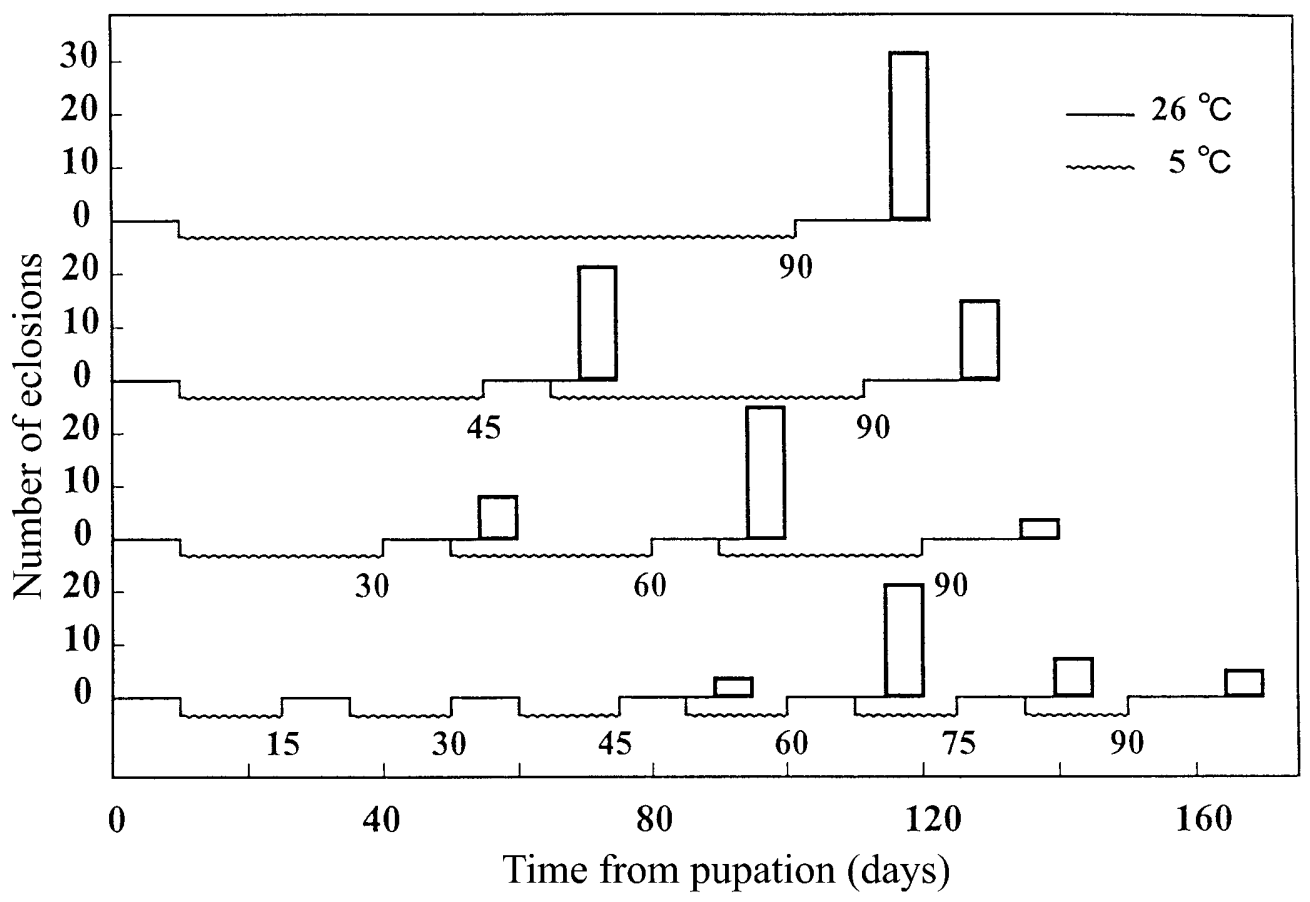

Fig. 14. Polymodal termination of winter diapause in $M$. brassicae caused by intermittent chilling and warming. The pupae showing a sign of adult morphogenesis within a week after transfer to $26^{\circ} \mathrm{C}$ were not returned to chilling (Masaki, 1956a).

ACKNOWLEDGEMENTS. On the occasion of the 90th anniversary of Professor A.S. Danilevsky's birthday and the 40th anniversary of the publication of his monumental book Fotoperiodizm i Sezonnoe Razvitie Nasekomykh, I pay a hearty tribute to this great pioneer in the ecophysiological study of seasonal adaptation in insects. His classic book has been indeed a rich source of useful information and ideas for many people for many years. To me, however, it is much more than that, because I was very much encouraged by this book soon after I started my research career. Danilevsky cited my earlier works published before 1960 , thereby introduced me to the community of scientists studying ecophysiology of the seasonal adaptation in insects.

My sincere thanks are due to Professor Kipyatkov and all other members of the organizing committee for inviting me to this memorable workshop, to my former colleagues and students who have been working with me over the last 40 years. My thanks are also due to Y. Ishiguri of Aomori Apple Experiment Station for the information on the spring emergence pattern of C. sasakii. I am gratefully indebted to David Denlinger for correcting English of the mauscript.

\section{REFERENCES}

ANDo Y. 1978: Studies on egg diapause in the false melon beetle, Atrachya menetriesi Faldermann (Coleoptera: Chrysomelidae). Bull. Fac. Agric. Hirosaki Univ. 30: 131-215. [in Japanese, English abstr.]

ANDO Y. 1993: Thermal response and reversibility of diapause in the eggs of Locusta migratoria. Physiol. Entomol. 18: 1-6.

Beck S.D. 1980: Insect Photoperiodism. 2nd edition, Academic Press, New York, 387 pp.

BRADShaw W.E. \& Lounibos L.P. 1977: Evolution of dormancy and its photoperiodic control in pitcher-plant mosquitoes. Evolution 31: 546-567.
DANILEVSKY A.S. 1957: Fotoperiodizm kak faktor obrazovaniya geograficheskikh rasu nasekomykh. Entomol.Obozr. 36: $5-27$.

Danilevsky A.S. 1961: Fotoperiodizm i Sezonnoe Razvitie Nasekomykh. Izdacheristvo Leningrad Univ., Leningrad, 243 pp.

Danks H.V. 1987: Insect Dormancy: An Ecological Perspective. Biological Survey of Canada (Terrestrial Arthropods), Ottawa, $439 \mathrm{pp}$.

DANKS H.V. 1991: Life cycle pathways and the analysis of complex life cycles in insects. Can. Entomol. 123: 23-40.

Denlinger D.L. \& Bradfield IV J.Y. 1981: Duration of pupal diapause in the tobacco hornworm is determined by number of short days received by the larvae. J. Exp. Biol. 91: 331-337.

Flanagan R.D., Tammariello S.P., Joplin K.H., Cikra-Irland R.A., Yocum G.D. \& Denlinger D.L. 1998: Diapause specific gene expression in pupae of the flesh fly Sarcophaga crassipalpis. Proc. Nat. Acad. Sci. USA 95: 5616-5620.

GRÜNER C. \& SAUER K.P. 1988: Aestival dormancy in the cabbage moth Mamestra brassicae L. (Lepidoptera: Noctuidae). 1. Adaptive significance of variability of two traits; daylength thresholds triggering aestival dormancy and duration of aestival dormancy. Oecologia 74: 515-523.

HigAKI M. \& ANDO Y. 2000: Effect of temperature on the termination of prolonged initial diapause in Eobiana japonica (Bolivar) (Orthoptera:Tettigoniidae). Entomol. Sci. 3: 219-226.

HoDeK I. 1996: Diapause development, diapause termination and the end of diapause. Eur. J. Entomol. 93: 475-487.

Hodek I. \& Hodková M. 1988: Multiple role of temperature during insect diapause: a mini review. Entomol. Exp. Appl. 49: $153-165$.

Horie Y., Kanda T. \& Mochida Y. 2000: Sorbitol as an arrester of embryonic development in diapausing eggs of the silkworm, Bombyx mori. J. Insect Physiol. 46: 1009-1016. 
Kai H., Kotani Y., Miao Y. \& Azuma M. 1995: Time interval measuring enzyme for resumption of embryonic development in the silkworm, Bombyx mori. J. Insect Physiol. 41: 905-910.

Kai H., Arai T. \& Yasuda F. 1999: Accomplishment of timeinterval activation of esterase A4 by simple removal of PIN fraction. Chronobiol. Intern. 16: 51-58.

Kalushrov P., Hodková M., Nedvěd O. \& Hodek I. 2001 Effect of thermoperiod on diapause intensity in Pyrrhocoris apterus (Heteroptera: Pyrrhocoridae). J. Insect Physiol. 47: $55-61$.

KIM D.-S., LEE J.-.H. \& YIEM M.-S. 2000: Spring emergence pattern of Carposina sasakii (Lepidoptera: Carposinidae) in apple orchards in Korea and its forecasting models based on degree-days. Environ. Entomol. 29: 1188-1198.

KIMURA M.T. 1988: Interspecific and geographic variation of diapause intensity and seasonal adaptation in the Drosophila aruraria species complex (Diptera: Drosophilidae). Func. Ecol. 2: 177-183.

Kimura T., Takano H. \& Masaki S. 1982: Photoperiodic programming of summer diapause after hibernation in Spilarctia imparilis Butler (Lepidoptera: Arctiidae). Appl. Entomol. Zool. 17: 218-226.

KIMURA Y. \& MASAKI S. 1992: Effect of light period on darktime measurement for diapause induction in Mamestra brassicae. J. Insect Physiol. 38: 681-686.

KimuRA Y. \& MASAKI S. 1998: Diapause programming with variable critical daylength under changing photoperiodic conditions in Mamestra brassicae. Entomol. Sci. 1: 467-475.

Koveos D.S., Hroon A. \& Veerman A. 1993: Geographic variation of diapause intensity in the spider mite Tetranychus urticae. Physiol. Entomol. 18: 50-56.

KRYSAN J.L. 1982: Diapause in the Nearctic species of virgifera group of Diabrotica: evidence for tropical origin and temperate adaptations. Ann. Entomol. Soc. Am. 75: 136-142.

MASAKI S. 1956a: The effect of temperature on the termination of pupal diapause in Barathra brassicae Linné (Lepidoptera: Noctuidae). Japan. J. Appl. Zool. 21: 97-107.

MASAKI S. 1956b: The local variation in the diapause pattern of the cabbage moth, Barathra brassicae Linné, with special reference to the aestival diapause (Lepidoptera: Noctuidae). Bull. Fac. Agric. Mie Univ. 13:29-46.

MASAKI S. 1958: The response of a "short-day" insect to certain external factors; the induction of diapause in Abraxas miranda Butler (Lepidoptera: Geometridae). Japan. J. Appl. Entomol. Zool. 2: 285-294.

MASAKI S. 1959: Seasonal changes in the mode of diapause in the pupae of Abraxas miranda Butler (Lepidoptera: Geometridae). Bull. Fac. Agric. Hirosaki Univ. 5: 14-27.

MASAKI S. 1963: Adaptation to local climatic conditions in the Emma field cricket (Orthoptera: Gryllidae). Konty $\hat{u}$ 31: 249-260.

MASAKI S. 1965: Geographic variation in the intrinsic incubation period: a physiological cline in the Emma field cricket (Orthoptera: Gryllidae: Teleogryllus). Bull. Fac. Agric. Hirosaki Univ. 11: 59-90.
MASAKI S. 1990: Opportunistic diapause in the subtropical ground cricket, Dianemobius fascipes. In: Gilbert E. (ed.): Insect Life Cycles: Genetics, Evolution and Coordination. Springer-Verlag, London, pp. 125-141.

MASAKI S. 1996: Geographical variation of life cycle in crickets (Ensifera: Grylloidea). Eur. J. Entomol. 93: 281-302.

MASAKI S. 1999: Seasonal adaptations of insects as revealed by latitudinal diapause clines. Entomol. Sci. 2: 539-549.

Masaki S., Ando Y. \& Watanabe A. 1979: High temperature and diapause termination in the eggs of Teleogryllus commodus (Orthoptera: Gryllidae). Kontyî 47: 493-504.

NakamuRa K. \& Numata H. 2000: Photoperiodic control of the intensity of diapause and diapause development in the bean bug, Riptortus clavatus (Heteroptera: Alydidae). Eur. J. Entomol. 97: 19-23.

NAGASE A. \& Masaki S. 1991: Thermal and photoperiodic responses in aestivating pupae of Dictyoploca japonica (Lepidoptera: Saturniidae). Appl. Entomol. Zool. 26: 387-396.

SAUnders D.S. 1982: Insect Clocks, 2nd ed. Pergamon Press, Oxford, 409 pp.

SAUNDERS D.S. 1987: Maternal influence on the incidence and duration of larval diapause in Calliphora vicina. Physiol. Entomol. 12: 331-338.

SAUNDERS D.S. 2000: Larval diapause duration and fat metabolism in three geographic strains of the blow fly, Calliphora vicina. J.Insect Physiol. 46: 509-517.

Sullrvan C.R. \& Wallace D.R. 1967: Interaction of temperature and photoperiod in the induction of prolonged diapause in Neodiprion sertifer. Can. Entomol. 99: 834-850.

Tani N., Kamada G., Ochiai K., Isibe I., Suwan S. \& Kai H. 2001: Carbohydrate moiety of time-interval measuring enzyme regulates time measurement through its interaction with time-holding peptide PIN. J. Biochem. 129: 221-227.

Tauber M.J., TAuber C.A. \& Masaki S. 1986: Seasonal Adaptations of Insects. Oxford Univ. Press, New York, 411 pp.

Topp W. 1990: Selection for an optimal monovoltine life cycle in an unpredictable environment. Studies on the beetle Catops nigricens Spence (Col.: Catopidae). Oecologia 84: 134-141.

UÉDA T. 1978: Geographic variation in the life cycle of Lestes sponsa. Tombo 21: 27-34.

WaLDBaurer G.P. 1978: Phenological adaptation and the polymodal emergence patterns of insects. In: Dingle H. (ed.): Evolution of Insect Migration and Diapause. Springer-Verlag, New York, pp. 127-144

WaldBauer G.P. \& Sternburg J.G. 1973: Polymorphic termination of diapause by cecropia: genetic and geographic aspects. Biol. Bull. 145: 627-641

WALdBaUer G.P. \& STERnburg J.G. 1986: The bimodal emergence of adult Hyalophora cecropia: Conditions required for the initiation of development by second mode pupae. Entomol. Exp. Appl. 41: 315-317.

YAMASHITA O. 1996: Diapause hormone of the silkworm, Bombyx mori: structure, gene expression and function. $J$. Insect Physiol. 42: 669-679.

Received November 9, 2001; revised February 5, 2002; accepted February 10, 2002 